\title{
Simulated Hyperglycemic Hyperosmolar Syndrome
}

\author{
IMPAIRED INSULIN AND EPINEPHRINE EFFECTS UPON LIPOLYSIS
}

IN THE ISOLATED RAT FAT CELL

\author{
B. Paul Turpin, William C. Duckworth, and Solomon S. Solomon, Departments \\ of Research and Medicine, Veterans Administration Medical Center and \\ University of Tennessee Center for the Health Sciences, \\ Memphis, Tennessee 38104
}

A B S T RA C T These investigations were designed to evaluate the effect of excess glucose and sodium chloride on lipolysis in the isolated adipocyte under normal and modelled pathological conditions simulating the hyperglycemic hyperosmolar syndrome.

Isolated rat fat cells were incubated in the presence of various combinations of sodium chloride, glucose, epinephrine, and insulin. Lipolysis was measured as glycerol and free fatty acid release, and total medium osmolarity as milliosmoles per liter by freezing point depression.

Basal lipolysis was unaffected by changes in osmolarity with sodium chloride, but glucose and glucose plus sodium chloride increased basal glycerol release. Increasing osmolarity with sodium chloride diminished the lipolytic response to epinephrine. Increasing osmolarity with glucose augmented the lipolytic response to epinephrine up to a total medium osmolarity of 550 mosmol. Higher osmolarities produced with glucose suppressed the epinephrine-induced lipolytic response.

When the hyperglycemic hyperosmolar syndrome was simulated with $100 \mathrm{mM}$ glucose and $50 \mathrm{mM}$ sodium chloride (total osmolarity $=460 \mathrm{mosmol}$ ) the epinephrine-stimulated lipolysis dose-response curve in the isolated fat cell was shifted to the right. Furthermore, in the presence of $100 \mathrm{mM}$ glucose $+50 \mathrm{mM}$ sodium chloride, physiological concentrations of insulin were less effective in opposing epinephrine-stimulated

This work was presented, in part, at the Midwest Section American Federation for Clinical Research, 1977.

Dr. Turpin is an Associate Investigator of the Veterans Administration. Dr. Duckworth is the recipient of Research Career Development Award AM 00187-01 from the U. S. Public Health Service.

Received for publication 23 February 1978 and in revised form 27 September 1978. lipolysis. In the presence of $50 \mathrm{mM}$ glucose and 25 $\mathrm{mM}$ sodium chloride (total osmolarity $=370 \mathrm{mosmol}$ ) epinephrine-stimulated lipolysis measured as free fatty acid release was decreased by $50 \%$.

Under conditions simulating the hyperglycemic hyperosmolar syndrome in the isolated rat adipocyte, altered lipolysis reflects impaired effectiveness of both insulin and epinephrine as antilipolytic and lipolytic hormones, respectively. Furthermore, the attenuated response to both hormones appears to be primarily a function of extracellular solute composition. The lack of ketosis is the result of diminished release of free fatty acids from peripheral adipose cells.

\section{INTRODUCTION}

The syndrome of hyperglycemia in the absence of ketonemia, hyperosmolarity of the serum, and low levels of peripheral blood immunoreactive insulin is well-established clinically as the hyperglycemic hyperosmolar syndrome (HHS) ${ }^{1}$ (1-3). Several hypotheses have been proposed to explain the absence of ketoacidosis in this diabetic condition. The development of ketoacidosis in the diabetic patient is a consequence of the relative insulin deficiency and resultant lack of antilipolysis. Excessive quantities of free fatty acids are mobilized from adipose tissue as a result of the unrestrained lipolysis. These free fatty acids are subsequently converted to acetate via acetyl-CoA. The elevated levels of free fatty acids also inhibit the metabolism of acetate through all pathways except those involved in ketone body formation (4). In HHS, plasma free fatty acid levels are low or normal (5) suggesting an effect on ketogenesis attributable to lack of substrate. Thus, absence of ketosis might reflect the

${ }^{1}$ Abbreviation used in this paper: HHS, hyperglycemic hyperosmolar syndrome. 
influence of multiple factors which regulate lipolysis and free fatty acid release from adipose tissue. It has been shown that insulin in low concentrations is more effective in inhibiting lipolysis in adipose tissue than in enhancing glucose use by peripheral tissues (6). This suggests that the low levels of insulin present in the HHS might be sufficient to suppress lipolysis. However, the similarities in insulin levels in hyperosmolar vs. ketoacidotic states militate against insulin being the sole antilipolytic factor in the HHS $(5,7)$.

\section{METHODS}

Animals. Male Holtzman rats which weighed 150-180 g were used. The animals were fed Purina Laboratory Chow (Ralston Purina Co., St. Louis, Mo.) ad libitum until time of sacrifice by decapitation.

Chemicals. Fatty acid-poor bovine serum albumin, fraction V, lot 27, was obtained from Miles Laboratories, Inc., Miles Research Products, Elkhart, Ind. Fatty acid-free bovine serum albumin fraction $\mathrm{V}$, lot 21 , was obtained from the same source. Crude bacterial collagenase, lot $43 \mathrm{~N} 111$, was purchased from Worthington Biochemical Corp., Freehold, N. J. Sodium Hepes and Hepes were purchased from Calbiochem, San Diego, Calif. Porcine insulin, lot 615-D63, was obtained from Eli Lilly and Company, Indianapolis, Ind. All other chemicals were of analytical grade and obtained from standard commercial sources.

Preparation of adipose cells. Isolated fat cells were prepared by the methods of Rodbell (8) and Gliemann (9) employing collagenase digestion as modified by Solomon et al. (10). Approximately $1.2 \mathrm{~g}$ of rat epididymal adipose tissue was used for each experiment. After collagenase digestion, cells were washed and then suspended in Krebs-Ringer Hepes buffer which contained $4 \%$ bovine serum albumin at $\mathrm{pH} 7.4$ and $37^{\circ} \mathrm{C}$. Cells were used both for incubation (8) and perifusion as described previously (11-13).

Incubation of isolated adipose cells. Cells were incubated in plastic vials in a total volume of $2.0 \mathrm{ml}$. Cells suspended in $1.0 \mathrm{ml}$ of isosmolar Krebs-Ringer Hepes buffer were added to $1.0 \mathrm{ml}$ of buffer containing various substances, depending upon the experiment. Vials were incubated in a metabolic shaker for $120 \mathrm{~min}$. The incubation was terminated by decanting the contents into chilled glass conical tubes and placing them in ice. The tubes were centrifuged at $1,800 \mathrm{rpm}$ for 20 min at $4^{\circ} \mathrm{C}$. The fat cake was removed and the supernatant fluid was assayed for glycerol and free fatty acid content. An aliquot of cells was taken for a cell count by the hanging-drop technique (10).

Perifusion of isolated fat cells. Isolated fat cells were studied with the perifusion system as previously described (11) with the following exceptions. During perifusion, glycerol release was continually monitored by the introduction into the system of an automated assay system (14) with the fluorometric method (15). The perifusion system was combined with a gradient maker to provide a perifusion medium with osmolarity decreasing from 1,000 mosmol to 280 mosmol.

Measurement of lipolysis. Glycerol content of the perifusate and the incubation medium was determined by the fluorometric method of Chernick (15). Glycerol release expressed as nanomoles glycerol per $10^{5}$ cells per hour was used as an index of lipolytic rate. Because of interexperimental variation in adipose cell responsiveness to hormone stimulation, results of some experiments are expressed on a percentage basis (11).
Free fatty acid concentration in the incubation medium was measured by chloroform extraction and colorimetric determination (16).

Measurement of osmolality. Hyperosmolar solutions of various agents were added to the incubation vials as $0.2-\mathrm{ml}$ vol. The final osmolarity of the $2.0-\mathrm{ml}$ vol was measured with a Fiske osmometer (Fiske Associates, Inc., Uxbridge, Mass.) to determine the freezing point depression.

Analysis of data. The data was evaluated for significance by the Student's $t$ test for non-paired data (17).

\section{RESULTS}

Effect of sodium chloride on basal lipolysis. Table I shows basal lipolysis under isosmolar $(280 \mathrm{mosmol})$ and hyperosmolar conditions $(350,450$, and 1,000 mosmol). It is evident that basal lipolysis was unaffected through this spectrum of extracellular osmolarity.

Effect of sodium chloride on epinephrine-stimulated lipolysis. Table I summarizes the effects of variation in extracellular sodium chloride osmoles on epinephrine-stimulated lipolysis in the incubation system. This group of experiments shows response to a submaximal stimulatory dose of epinephrine, $0.3 \mu \mathrm{M}$. Under hyperosmolar conditions, although lipolysis was augmented somewhat, this was not a statistically significant increase (data not shown). Epinephrine-stimulated lipolysis at $280 \mathrm{mosmol}$ was $157 \pm 15$ (SEM) nmol glycerol/ $10^{5}$ cells per $h$. With increasing osmolarity, the lipolytic response to epinephrine was progressively suppressed as compared with 280 mosmol. The effect of sodium chloride on epinephrine-stimulated lipolysis was also evaluated with perifused isolated fat cells (11-13). This system was used to determine if the effects of hyperosmolarity were reversible. $0.5 \mu \mathrm{M}$ epinephrine was present in the perifusion medium. Fig. 1 is a representative experiment showing the effect of hyperosmolarity in suppressing lipolysis in the

\section{TABLE I}

The Effect of Changing Extracellular Osmolarity with Sodium Chloride on Basal and Epinephrine-Stimulated Lipolysis in the Incubated Isolated Fat Cell

\begin{tabular}{ccc}
\hline & \multicolumn{2}{c}{ Glycerol release } \\
\cline { 2 - 3 } Osmolarity & Basal, $n=3$ & $\begin{array}{c}\text { Epinephrine stimulation } \\
(0.3 \mu \mathrm{M}) n=9\end{array}$ \\
\hline mosmolliter & & nmol/10 cells $/ \mathrm{h}$ \\
280 & $11 \pm 1^{*}$ & $157 \pm 15$ \\
350 & $12 \pm 1 \ddagger$ & $111 \pm 12 \oint$ \\
450 & $13 \pm 1 \ddagger$ & $38 \pm 6 \S$ \\
1,000 & $9 \pm 1 \ddagger$ & $6 \pm 1 \S$ \\
\hline
\end{tabular}

* Values shown are SEM.

‡ NS compared with basal at 280 mosmol.

$\$ P<0.001$ compared with epinephrine response at 280 mosmol. 


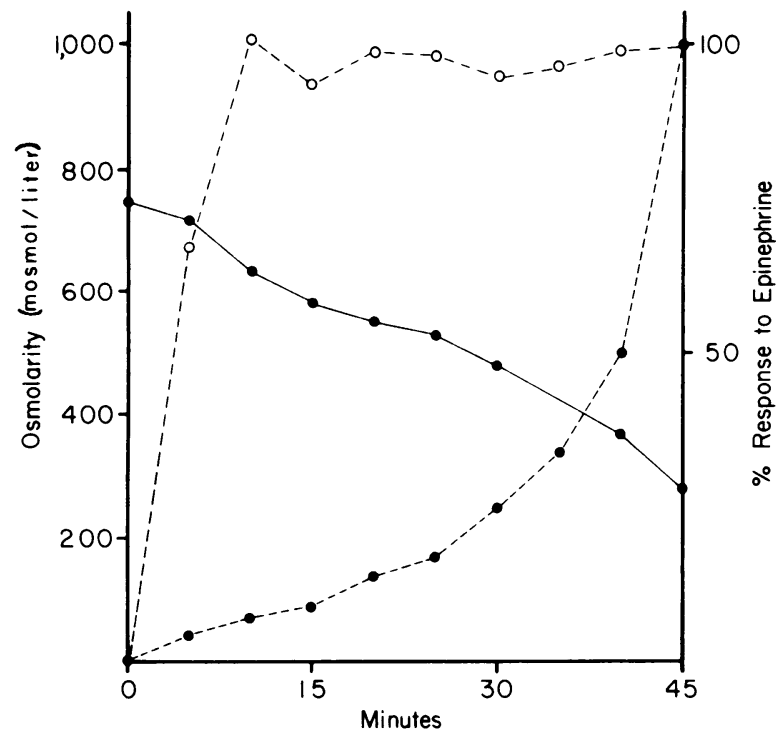

FIGURE 1 The effect of hyperosmolarity as a result of sodium chloride on lipolysis in the perifused isolated rat adipocyte. The perifusion buffer contained $0.5 \mu \mathrm{M}$ epinephrine. As the osmolarity (-O) decreases, lipolysis (- - - increases. For comparison, the effect of a constant infusion of epinephrine in isosmolar buffer is shown $(\mathrm{O}-\mathrm{O})$.

presence of a submaximal stimulatory dose of epinephrine. As the osmolarity declined, the lipolytic effect of the epinephrine became apparent at $\cong 650$ mosmol. Lipolysis increased in a smooth fashion until the isosmolar state was reached. The magnitude of the lipolytic response was similar to that seen when the isolated fat cells were perifused with $0.5 \mu \mathrm{M}$ epinephrine in isosmolar buffer. These results demonstrate that hypertonicity produces no irreversible alteration in lipolytic response. The contour of the graph showing lipolysis suggests also that there may be more than one component to the sodium chloride effect. The increment in effectiveness of epinephrine between 750 and 550 mosmol was less than between 550 and 350 mosmol. Similarly, the effectiveness of epinephrine markedly increased between 350 and 280 mosmol.

Effect of glucose on basal and epinephrine-stimulated lipolysis. Fig. 2 shows the effect of glucose on lipolysis in the incubated isolated fat cell. Basal lipolysis was progressively augmented by increases in extracellular osmolarity with glucose. In the absence of glucose ( $280 \mathrm{mosmol}$ ) basal lipolysis was $4 \mathrm{nmol}$ glycerol/ $10^{5}$ cells per $\mathrm{h}$; addition of $100 \mathrm{mM}$ glucose increased the lipolytic rate to $13 \pm 1$. With $300 \mathrm{mM}$ glucose, lipolysis was $20 \pm 1$; and with $1,000 \mathrm{mM}$ glucose, $31 \pm 1$. Adjacent values are significantly different from each other with $P<0.001$.

Lipolytic response to epinephrine was augmented by addition of glucose. Increasing the concentration of

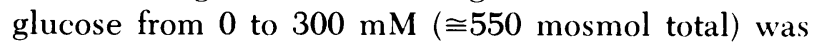
associated with an increase in response. Higher concentrations of glucose produced less augmentation of the response to epinephrine, and at $500 \mathrm{mM}$ glucose the response to epinephrine was less than under isosmolar conditions. No response to epinephrine was seen at $1,000 \mathrm{mM}$ glucose.

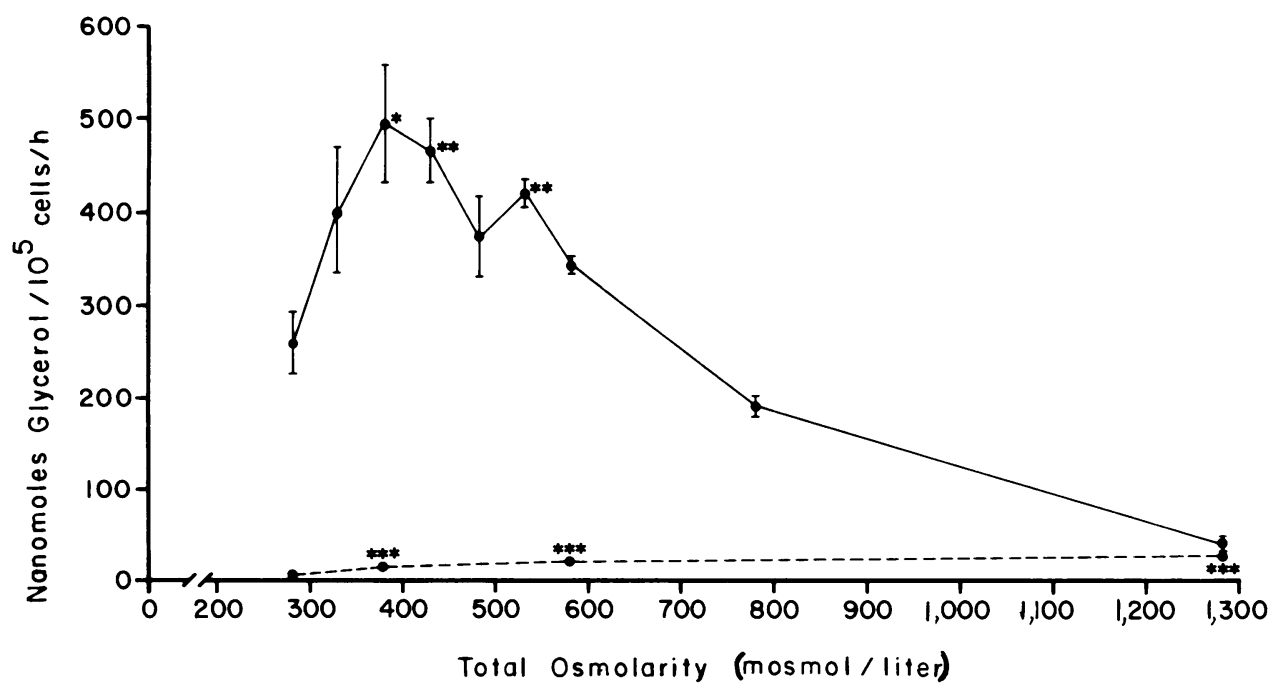

FIGURE 2 A representative experiment showing the effect of increasing osmolarity produced by glucose on lipolysis in the isolated rat adipocyte. Each point represents the mean \pm SEM $(n=3)$. There is no glucose present at $280 \mathrm{mosmol}$. Response to $0.5 \mu \mathrm{M}$ epinephrine (-) is augmented by addition of glucose to produce total osmolarity of 580 mosmol $(300 \mathrm{mM}$ glucose). Basal lipolysis $(---)$ is progressively increased by addition of glucose. ${ }^{*} P<0.02$; ${ }^{* *} P<0.01 ;{ }^{* * *} P<0.001$. 
These results indicate that in the isolated fat cell, hyperosmolarity as a result of glucose at concentrations $<300 \mathrm{mM}$ augments both basal and epinephrine-stimulated lipolysis. This contrasts with the effect of sodium chloride on lipolysis. Basal lipolysis was unaffected by changes in extracellular sodium chloride concentration, but epinephrine-sensitive lipolysis could be completely inhibited by sodium chloride. Because glucose and sodium chloride are the major determinants of hyperosmolarity in the HHS, an in vitro simulation of the syndrome was formulated with $100 \mathrm{mM}$ glucose and $50 \mathrm{mM}$ sodium chloride added to isosmolar buffer.

Effect of glucose and sodium chloride on insulin inhibition of stimulated lipolysis. In the series of incubation experiments represented in Table II, 0.5 $\mu \mathrm{M}$ epinephrine, a submaximal stimulatory dose, increased lipolysis $300 \pm 25 \mathrm{nmol}$ glycerol $/ 10^{5}$ cells per $\mathrm{h}$ above basal $(20 \pm 4)$. A maximal response was attained with $1.0 \mu \mathrm{M}$ epinephrine, $625 \pm 80$. Insulin, 5 $\mu \mathrm{U} / \mathrm{ml}$, inhibited the response to $0.5 \mu \mathrm{M}$ epinephrine by $71 \%(P<0.001)$. It is also seen in these experiments that $50 \mathrm{mM}$ sodium chloride and $100 \mathrm{mM}$ glucose inhibited and augmented, respectively, the lipolytic response to $0.5 \mu \mathrm{M}$ epinephrine. Insulin, $5 \mu \mathrm{U} / \mathrm{ml}$, inhibited lipolysis in the presence of $0.5 \mu \mathrm{M}$ epinephrine and $50 \mathrm{mM}$ sodium chloride by $39 \%$. This compares with $55 \%$ inhibition by insulin in the presence of $100 \mathrm{mM}$ glucose. When $0.5 \mu \mathrm{M}$ epinephrine was combined with $50 \mathrm{mM}$ sodium chloride and $100 \mathrm{mM}$ glucose, the lipolytic response was attenuated when compared with epinephrine alone $(P<0.01)$. The effectiveness of insulin as an antilipolytic hormone in the presence of these solutes was likewise attenuated, $47 \%$ inhibition. This effect was examined more closely in the following series of experiments.

Effectiveness of insulin and epinephrine in simu-

TABLE II

The Effect of Insulin on Epinephrine-Stimulated Lipolysis under Hyperosmolar Conditions

\begin{tabular}{lccc}
\hline & & \multicolumn{2}{c}{ Lipolysis } \\
\cline { 3 - 4 } \multicolumn{1}{c}{ Addition } & Osmolarity & $\begin{array}{c}0.5 \mu \mathrm{M} \\
\text { EPI* }\end{array}$ & $\begin{array}{c}0.5 \mu \mathrm{M} \\
\mathrm{EPI}+5 \\
\mu \mathrm{U} \mathrm{In} / \mathrm{mlt}\end{array}$ \\
\hline & mosmolliter & $\begin{array}{c}n \text { nol glycerol } 10^{5} \text { cells/h } \\
\text { above basal }\end{array}$ \\
& & $300 \pm 25 \S$ & $86 \pm 16$ \\
None & 280 & $160 \pm 23$ & $99 \pm 8$ \\
$50 \mathrm{mM} \mathrm{NaCl}$ & 380 & $700 \pm 36$ & $316 \pm 31$ \\
$100 \mathrm{mM} \mathrm{Glucose}$ & 380 & $240 \pm 27$ & $125 \pm 16$ \\
$50 \mathrm{mM} \mathrm{NaCl}$ and & & \multicolumn{2}{c}{} \\
$100 \mathrm{mM} \mathrm{Glucose}$ & 460 & &
\end{tabular}

* EPI = Epinephrine.

$\$$ In $=$ Insulin.

$\S$ Values shown are SEM.

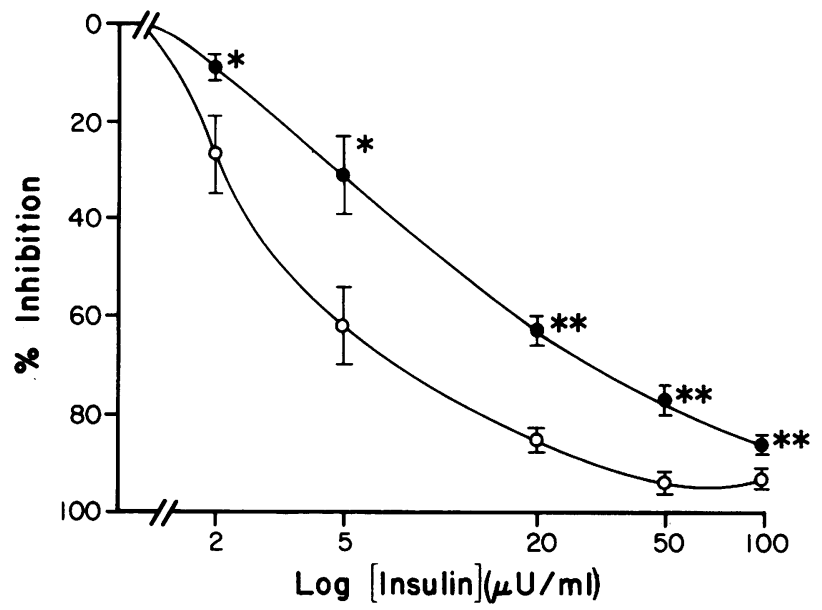

FIGURE 3 Inhibition by insulin of epinephrine-stimulated lipolysis. In hyperosmolar medium (460 mosmol, - - ) produced with $100 \mathrm{mM}$ glucose and $50 \mathrm{mM}$ sodium chloride, all concentrations of insulin examined are less effective in opposing epinephrine-stimulated lipolysis than in isosmolar medium (O_O). $n=6 ;{ }^{*} P<0.05$; ${ }^{* * P}<0.001$.

lated HHS. The dose-response curves for insulin inhibition of epinephrine-stimulated lipolysis in the incubation system under isosmolar and hyperosmolar conditions are represented in Fig. 3. In isosmolar medium (280 mosmol), $0.5 \mu \mathrm{M}$ epinephrine-stimulated lipolysis above basal $485 \pm 30 \mathrm{nmol}$ glycerol $/ 10^{5}$ cells per h. In hyperosmolar medium ( $100 \mathrm{mM}$ glucose and $50 \mathrm{mM}$ sodium chloride, $\cong 460$ mosmol), lipolytic response to $0.5 \mu \mathrm{M}$ epinephrine was $342 \pm 24 \mathrm{nmol}$ glycerol $/ 10^{5}$ cells per $\mathrm{h}$ above basal. All concentrations of insulin were less effective under hyperosmolar conditions in opposing epinephrine-stimulated lipolysis than in isosmolar medium. $5 \mu \mathrm{U}$ insulin $/ \mathrm{ml}$ in hyperosmolar medium inhibited lipolysis by $31 \%$. This compares with $62 \%$ inhibition in isosmolar medium $(P<0.05)$. With $20 \mu \mathrm{U}$ insulin $/ \mathrm{ml}$, inhibition was $63 \%$ vs. $85 \%(P<0.001)$. Even at $100 \mu \mathrm{U}$ insulin $/ \mathrm{ml}$, lipolysis was not completely suppressed in hyperosmolar medium.

Impaired effectiveness of insulin under conditions simulating the HHS does not explain the restrained lipolysis characteristic of the syndrome. Therefore, the lipolytic potency of epinephrine was examined under similar experimental conditions. Fig. 4 is a representative experiment showing the dose-response curves for epinephrine-stimulated lipolysis under both isosmolar and hyperosmolar conditions. It is seen that hyperosmolar medium is associated with a decrease in responsiveness of the adipocyte to epinephrine.

Effect of glucose and sodium chloride on free fatty acid release. Although glycerol release is an accurate measurement of total hydrolysis of triglyceride, release of free fatty acid more accurately reflects the net con- 


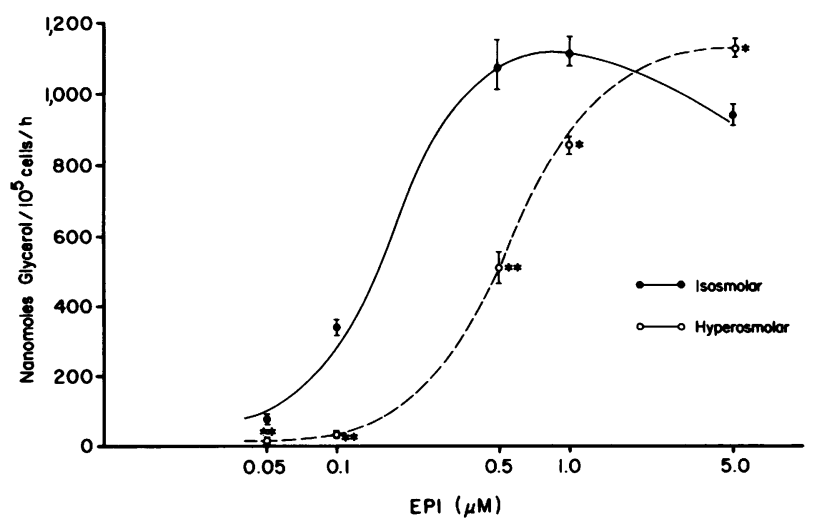

FIGURE 4 Responsiveness of adipocytes to epinephrine (EPI) in hyperosmolar medium. Hyperosmolar medium $(\mathrm{O}--\mathrm{O})$ produced with $100 \mathrm{mM}$ glucose and $50 \mathrm{mM}$ sodium chloride is associated with a decreased responsiveness of the adipocytes to epinephrine. $n=3$; ${ }^{*} P<0.01$; ${ }^{* *} P<0.001$.

version of triglyceride to free fatty acids. The next series of incubation experiments was performed with $50 \mathrm{mM}$ glucose (a concentration well within the range seen in HHS) and excess sodium chloride $12.5,25$, and $50 \mathrm{mM}$ in the presence of $1.0 \mathrm{mM}$ epinephrine (a submaximal stimulatory dose in this series of experiments). Fig. 5 shows the change from basal in free fatty acid release under various conditions. $50 \mathrm{mM}$ glucose inhibits both stimulated $(P<0.05)$ and basal $(P$ $<0.05)$ fatty acid release. Glucose in the presence of $12.5 \mathrm{mM} \mathrm{NaCl}$ is not more effective than glucose alone in suppressing fatty acid release; but $25 \mathrm{mM} \mathrm{NaCl}$ (total medium sodium osmoles $=170$ ) in the presence of glucose markedly diminishes fatty acid release $(P<0.01)$. This effect is even more pronounced with $50 \mathrm{mM}$ sodium chloride $(P<0.001)$. Epinephrine-induced free fatty acid release was also inhibited by hyperosmolarity as a result of sodium chloride excess alone. Sodium chloride excess $(25,50$, and $100 \mathrm{mM})$ inhibited fatty acid release by 12,19 , and $65 \%$, respectively. This degree of inhibition of free fatty acid release was very similar to that of inhibition of glycerol release (Table I) which shows that glycerol release was inhibited by sodium chloride excess (70 and $170 \mathrm{mM}$ ) by 28 and $76 \%$, respectively.

\section{DISCUSSION}

Investigations of adipose tissue and isolated adipose cells with hyperosmolar solutions of sucrose, mannitol, sodium chloride, and urea have shown increased transport of glucose across the plasma membrane (18-21); increased incorporation of ${ }^{14} \mathrm{C}$-labeled glucose into $\mathrm{CO}_{2}$, total lipid, free fatty acids, and glycerol (18); attenuation of lipolysis and release of free fatty acids in response to lipolytic agents $(18,22)$; and augmentation of increases in intracellular concentrations of cyclic AMP in response to lipolytic hormones (22). With the exception of the last mentioned effect, these changes in metabolic parameters are similar to, and parallel those, produced by insulin.

In 1963, Jungas and Ball showed that epinephrine, in the presence of glucose, was more effective in stimulating lipolysis in epididymal adipose tissue than epinephrine alone (23). These studies were confirmed by later work which emphasized the role of nonesterified fatty acids as regulators of net lipolysis $(24,25)$. Physiologic or superphysiologic concentrations of glucose are associated with reesterification of intracellular free fatty acids with a subsequent lowering of the concentration of these organic acids. This is associated with increased net lipolysis, both basal and stimulated, as reflected by glycerol which is the most accurate measurement of triglyceride hydrolysis (25-28). Because of the reesterification of the fatty acids, however, fatty acid release is usually decreased when glucose is present in the incubation media $(18,29)$.

The distinguishing feature of the HHS, when com-

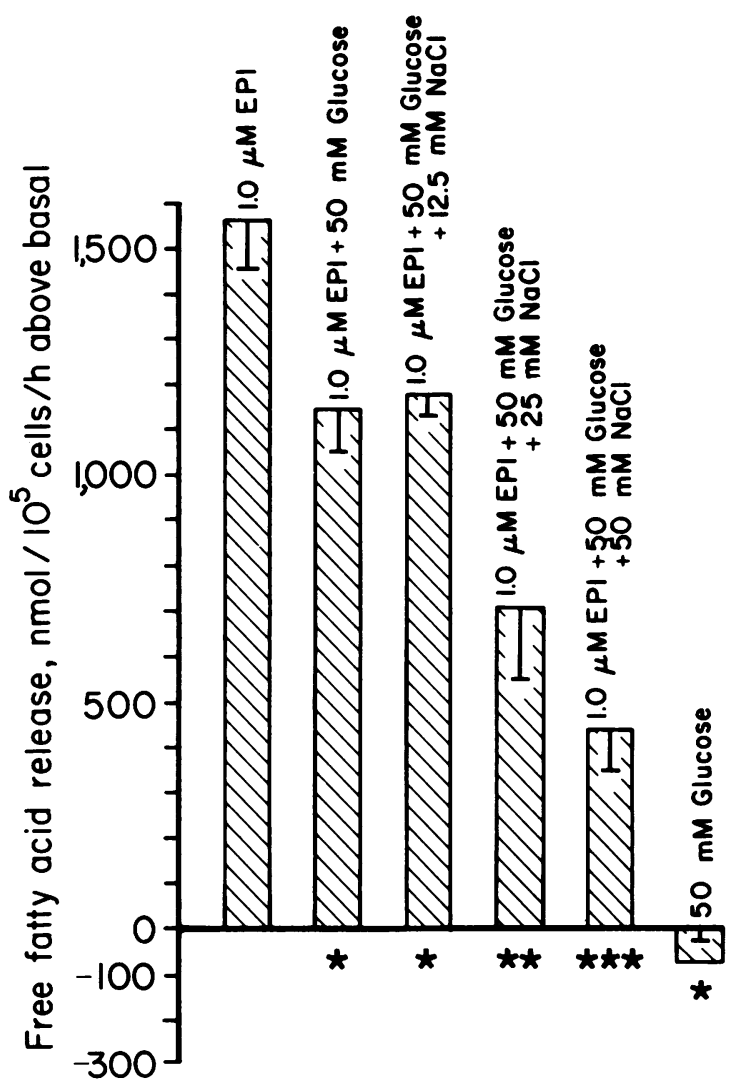

FIGURE 5 Inhibition of epinephrine (EPI)-stimulated free fatty acid release by hyperosmolar medium containing $50 \mathrm{mM}$ glucose alone and combined with sodium chloride (mean \pm SEM $n=4) ;{ }^{*} P<0.05 ;{ }^{* *} P<0.01 ;{ }^{* *} P<0.001$. Statistical comparison with $1.0 \mu \mathrm{M}$ epinephrine alone or with basal for glucose alone. 
pared with other insulinopenic states, is the absence of ketogenesis of sufficient magnitude to produce ketoacidosis. It has been proposed that ketone body production is low because of deficient substrate in the form of free fatty acids. It would appear that in HHS the liver may not be exposed to sufficient insulin to prevent ketogenesis (5) as plasma insulin levels are similar to those seen in diabetic ketoacidosis. However, the low levels of plasma free fatty acids seen in the majority of patients with the HHS do indicate that free fatty acid release by peripheral adipose tissue is inhibited. One major unanswered question relates to the factors responsible for restrained lipolysis in the adipose cell under these conditions. Dehydration and volume depletion associated with decreased food intake have been shown to have an effect in lowering circulating free fatty acids (30-32). Similarly, a nonsuppressible insulin-like agent (a somatomedin) has been suggested as an antilipolytic factor in this syndrome (33). However, the effects of these and other hormones with antilipolytic properties have not been evaluated in this syndrome.

The results of our studies and others have shown that glucose enhances both basal and stimulated lipolysis, as reflected in glycerol release, in adipose tissue, and in isolated adipocytes (24-26). The maximal effect on epinephrine-stimulated glycerol output was seen at $100 \mathrm{mM}$ glucose with higher levels of glucose that produced less of a stimulatory effect as well as very high glucose levels, actually blocking epinephrineinduced lipolysis. In contrast, basal lipolysis was increased at all levels of glucose.

Although most concentrations of glucose augmented epinephrine-induced glycerol output, sodium chloride was able to abolish this effect of glucose. Indeed, the effect of sodium chloride as an inhibitor of lipolysis was more striking against the combination of epinephrine and glucose than against epinephrine alone. Sodium chloride negated the enhancement produced by glucose of epinephrine-stimulated lipolysis. These observations demonstrate that the net effect of sodium chloride in the presence of glucose is antilipolytic.

Hyperosmolarity induced by excess sodium chloride alone inhibited epinephrine-induced lipolysis. Both glycerol and fatty acid release were decreased in the presence of as little as $25 \mathrm{mM}$ sodium chloride excess. Sodium chloride is apparently capable of restraining lipolysis measured as glycerol or free fatty acid release under conditions simulating the HHS. It is thought that hyperosmolarity increases glucose uptake through a nonspecific effect of tonicity rather than through the effects of a particular solute (20). The antilipolytic effect of sodium chloride might be produced through inhibition of free fatty acid reesterification or inhibition of the passage of products of lipolysis through the cell membrane. Either mechanism would result in levels of intracellular free fatty acids sufficiently high to inhibit lipolysis. Extracellular sodium chloride in higher than physiologic concentrations may interfere with the $\mathrm{Na}^{+}, \mathrm{K}^{+}$-ATPase mechanism, which has been linked with active transport of free fatty acids $(34,35)$.

When insulin was present in physiologic concentrations, its effect in opposing lipolysis was less under hyperosmolar than isosmolar conditions. This might represent a combined enhancement of hyperosmolarity and insulin on glucose uptake. However, the ability of insulin to stimulate glucose uptake in muscle preparations under hyperosmolar conditions has been shown to be diminished (4). Furthermore, the antilipolytic effect of hyperosmolarity is not additive to insulin. In contrast, insulin was less effective under these conditions. These results are most interesting when compared with a recent report of diminished lipolysis associated with increased intracellular cyclic AMP after lipolytic hormone stimulation under hyperosmolar conditions. Although hyperosmolarity in those experiments augmented increases in intracellular cyclic AMP in response to a lipolytic hormone, lipolysis did not proceed at a commensurate rate (7). This strongly suggests inhibition of the system beyond the step of cyclic AMP accumulation. When hyperosmolar conditions were produced with glucose and sodium chloride, our results showed a decreased responsiveness of the adipocyte to epinephrine, but no change in maximal lipolysis.

We have shown that physiological concentrations of insulin are less effective in opposing lipolysis under conditions simulating the HHS. Hence, the diminished lipolysis seen in this insulinopenic state cannot be attributed to increased effectiveness of insulin. Rather, it appears that the absence of ketosis in this syndrome might represent decreased responsiveness to catecholamines as reflected in the release of free fatty acids from peripheral adipose tissue.

Our results suggest that specific solute effects are more likely responsible for the clinical presentation in this syndrome, perhaps through perturbations in levels of free fatty acids.

\section{ACKNOWLEDGMENTS}

The authors wish to thank Dr. C. T. Huber for technical advice on the perifusion of isolated fat cells, and also Ms. Margaret Goessling and Ms. Janice New for expert technical assistance.

This study was conducted under Veterans Administration Research Projects 8036-01, 8036-04, 1942-04, and 8569-01; and was supported, in part, by National Institutes of Health grant AM 18022, and by a grant from the Juvenile Diabetes Foundation. 


\section{REFERENCES}

1. DeGraeff, J., and J. B. Lips. 1957. Hypernatremia in diabetes mellitus. Acta Med. Scand. 157: 71-78.

2. Gordon, E. E., and U. M. Kabadi. 1976. The hyperglycemic hyperosmolar syndrome. Am. J. Med. Sci. 271: 253-268.

3. Foster, D. W. 1974. Insulin deficiency and hyperosmolar coma. Adv. Intern. Med. 19: 159-173.

4. Wieland, O. 1965. On the nature and treatment of diabetes. Excerpta Med. Int. Congr. Ser. 172: 533-535.

5. Gerich, J. E., M. M. Martin, and L. Recant. 1971. Clinical and metabolic characteristics of hyperosmolar nonketotic coma. Diabetes. 20: 228-238.

6. Zierler, K., and D. Rabinowitz. 1963. Roles of insulin and growth hormone, based on studies of forearm metabolism in man. Medicine (Baltimore). 42: 385-402.

7. Arieff, A. I., and H. J. Carroll. 1972. Non-ketotic hyperosmolar coma with hyperglycemia: clinical features, pathophysiology, renal function, acid-base balance, plasma-cerebrospinal fluid equilibria and the effects of therapy in 37 cases. Medicine (Baltimore). 51: 73-94.

8. Rodbell, M. 1964. Metabolism of isolated fat cells. I. Effects of hormones on glucose metabolism and lipolysis. J. Biol. Chem. 239: 375-380.

9. Gliemann, J. 1965. Insulin-like activity of dilute human serum assayed by isolated adipose tissue cell method. Diabetes. 14: 643-649.

10. Solomon, S. S., L. E. King, Jr., and K. Hashimoto. 1975. Studies of the biological activity of insulin, cyclic nucleotides and concanavalin A in the isolated fat cell. Horm. Metab. Res. 7: 297-304.

11. Turpin, B. P., W. C. Duckworth, and S. S. Solomon. 1977. Perifusion of isolated rat adipose cells. Modulation of lipolysis by adenosine. J. Clin. Invest. 60: 442-448.

12. Katocs, A. S., Jr., E. E. Largis, D. O. Allen, and J. Ashmore. 1973. Perifused fat cells: Effects of lipolytic agents. J. Biol. Chem. 248: 5089-5094.

13. Solomon, S. S., and W. C. Duckworth. 1976. Effect of antecedent hormone administration on lipolysis in the perifused isolated fat cell. J. Lab. Clin. Med. 88: 984-994.

14. Huber, C. T., W. C. Duckworth, and S. S. Solomon. 1978. A continuous automated assay of lipolysis during perifusion of isolated fat cells. Anal. Biochem. 85: 239-250.

15. Chernick, S. S. 1969. Determination of glycerol in acyl glycerol. Methods Enzymol. 14: 627-630.

16. Duncombe, W. G. 1963. The colorimetric micro-determination of long-chain fatty acids. Biochem. J. 88: 7-10.

17. Diem, K., and C. Lentner, editors. 1970. Scientific Tables. CIBA/Geigy Ltd., Basel, Switzerland. 158-159.

18. Kuzuya, T., E. Samols, and R. H. Williams. 1965. Stimulation by hyperosmolarity of glucose metabolism in rat adipose tissue and diaphragm in vitro. J. Biol. Chem. 240: 2277-2283.

19. Clausen, T. 1965. The relationship between the transport of glucose and cations across cell membranes in isolated tissues. I. Stimulation of glycogen deposition and inhibition of lactic acid production in diaphragm, induced by ouabain. Biochim. Biophys. Acta. 109: 164-171.
20. Clausen, T. 1968. The relationship between the transport of glucose and cations across cell membranes in isolated tissues. III. The effect of $\mathrm{Na}^{+}$and hyperosmolarity on glucose metabolism and insulin responsiveness in isolated rat hemidiaphragm. Biochim. Biophys. Acta. 150: 56-65.

21. Clausen, T., J. Gliemann, J. Vinten, and P. G. Kohn. 1970. Stimulating effect of hyperosmolarity on glucose transport in adipocytes and muscle cells. Biochim. Biophys. Acta. 211: 233-243.

22. Wada, M., Y. Akanuma, N. Kimura, and N. Nagata. 1976. Effects of hyperosmolarity on the cyclic AMP concentration and lipolysis of the adipocyte stimulated by adrenocorticotropic hormone. Endocrinology. 98: 84-90.

23. Jungas, R. L., and E. G. Ball. 1963. Studies on the metabolism of adipose tissue. XII. The effects of insulin and epinephrine on free fatty acid and glycerol production in the presence and absence of glucose. Biochemistry. 2: 383-388.

24. Bally, P. R., H. Kappeler, E. R. Froesch, and A. Labhart. 1965. Effect of glucose on spontaneous limitation of lipolysis in isolated adipose tissue: a potential regulatory mechanism. Ann. N. Y. Acad. Sci. 131: 143-156.

25. Carlson, L. A. 1965. Inhibition of the mobilization of free faty acids from adipose tissue. Ann. N. Y. Acad. Sci. 131: 119-142.

26. Naito, C., and K. Okada. 1975. Effect of glucose on lipolysis and on release of lipolytic products in isolated adipocytes. Am. J. Physiol. 228: 92-97.

27. Björntorp, P., and J. Östman. 1971. Human adipose tissue dynamics and regulation. Advan. Metab. Disord. 5: 277-327.

28. Chlouverakis, C. 1967. The action of glucose on lipolysis. Metab. Clin. Exp. 16: 469-472.

29. Vaughn, M. 1962. The production and release of glycerol by adipose tissue incubated in vitro. J. Biol. Chem. 237: 3354-3358.

30. Mirsky, I. A. 1963. Effect of oxytocin, vasopressin, and related peptides on plasma free fatty acids. Am. J. Physiol. 204: 842-846.

31. Gerich, J., J. C. Penhos, R. A. Gutman, and L. Recant. 1973. Effect of dehydration and hyperosmolarity on glucose, free fatty acid and ketone body metabolism in the rat. Diabetes. 22: 264-271.

32. Kleeman, C. R., and M. P. Fickmon. 1967. The clinical physiology of water metabolism. N. Engl. J. Med. 27: 1300-1307.

33. Clemmons, D. R., R. L. Hintz, and L. E. Underwood. 1975. Common mechanism of action of somatomedin and insulin on fat cells - further evidence. In Heterogeneity of Polypeptide Hormones. D. Rabinowitz and J. Roth, editors. Academic Press, Inc., New York. 65-71.

34. Schimmel, R. J., and H. M. Goodman. 1971. Efflux of free fatty acids from adipose tissue. Am. J. Physiol. 221: $118-122$.

35. Ho, R. J., B. Jeanrenaud, and A. E. Renold. 1966. Ouabainsensitive fatty acid release from isolated fat cells. $E x$ perientia (Basel). 22: 86-87. 